\title{
THE EFFECTS OF NATIONAL HEALTH INSURANCE PERCEPTION AND INFORMATION ACCESS ON THE UTILIZATION OF HEALTH SERVICE IN PEMATANG SIANTAR, NORTH SUMATERA
}

\author{
Zakia Husna Nasution, Zulfendri, Destanul Aulia
}

Masters Program in Public Health, Universitas Sumatera Utara

\begin{abstract}
Background: Financial protection is at the core of the national health insurance (NHI). Financial protection is achieved when direct payments made to obtain health services needed do not expose people to financial hardship. This study aimed to examine the effects of NHI perception and information access on the utilization of health service in Pematang Siantar, North Sumatera.

Subjects and Method: This was a cross sectional study conducted at Pematangsiantar, North Sumatera. A sample of 140 people was selected for this study. The dependent variable was ulilization of health service. The independent variables were perception of NHI, and information access. The data were collected by questionnaire. Associations between variables were tested by chi-square with OR as the measure of association.

Results: Utilization of health service increased with positive perception of NHI $(\mathrm{OR}=2.34 ; \mathrm{p}=0.001)$ and good information access $(\mathrm{OR}=1.73 ; \mathrm{p}=0.002)$.

Conclusion: Utilization of health service increases with positive perception of NHI and good information access.
\end{abstract}

Keywords: utilization of health service, national health insurance, perception, information access.

\section{Correspondence:}

Zakia Husna Nasution. Masters Program in Public Health, Universitas Sumatera Utara, Medan, North Sumatera. Email: husna_zakia@yahoo.com.

Mobile: 08126455415. 